\title{
PEMANFAATAN ZOOM MEETING UNTUK PROSES PEMBELAJARAN PADA MASA PANDEMI COVID-19
}

\author{
Danin Haqien ${ }^{1}$, Aqiilah Afiifadiyah Rahman ${ }^{2}$ \\ Pendidikan Sejarah, FKIP, Universitas Muhammadiyah Prof. Dr. HAMKA Jakarta ${ }^{1,2}$ \\ Email: dhaqien5150@gmail.com ${ }^{1}$
}

\begin{abstract}
Abstrak
Saat masa pandemi COVID-19, setiap universitas di Jakarta dan Depok melakukan sistem pembelajaran jarak jauh. Aplikasi yang banyak digunakan saat pembelajaran jarak jauh ialah Zoom Meeting. Penelitian ini dilakukan untuk mengetahui seberapa efektifnya penggunaan aplikasi Zoom Meeting terhadap para mahasiswa di Jakarta dan Depok ketika pandemi COVID-19. Penelitian ini bersifat kualitatif dan menggunakan metode grounded theory. Teknik pengumpulan data dilakukan dengan wawancara melalui Google Form dan Whatsapp kepada tiga puluh dua mahasiswa Universitas di Jakarta dan Depok. Hasil penelitian ini, menunjukkan bahwa penggunaan aplikasi Zoom Meeting tidak begitu efektif bagi para mahasiswa Universitas di Jakarta dan Depok. Tetapi, aplikasi Zoom Meeting lebih baik karena dalam aplikasi Zoom Meeting komunikasi antara individu dilakukan secara lisan dibandingkan penggunaan aplikasi pembelajaran yang melakukan kegiatan komunikasi secara tertulis menurut teori komunikasi pendidikan.
\end{abstract}

Kata Kunci : Zoom meeting, Mahasiswa, Komunikasi

\begin{abstract}
During the COVID-19 pandemic, each university in Jakarta and Depok performs a distance learning system. A widely used application during distance learning is a Zoom Meeting. This research was conducted to know the effectiveness of Zoom Meeting application to students in Jakarta and Depok during COVID-19 Pandemic. This research was a qualitative with grounded theory method. Data collection techniques were conducted with interviews through Google Form and Whatsapp to thirty two university students in Jakarta and Depok. The results of this study, showed that the use of Zoom Meeting application was not very effective for university students in Jakarta and Depok. However, the Zoom Meeting app was better because, in the application of Zoom Meeting communication between individuals was done orally compared to the use of a learning application that conductedwritten communication activities according to education communication theory.
\end{abstract}

Key Words : Zoom Meeting, Student, Communication

\section{PENDAHULUAN}

Pada masa sekarang ini, dunia sedang dihadapkan dengan fenomena yang berkaitan dengan masalah kesehatan yaitu corona virus atau COVID-19, banyak negara yang terkena dampak virus ini, Indonesia termasuk salah satunya. Untuk itu pemerintah mengambil kebijakan dengan menerapkan social distancing untuk meminimalisir penularan COVID19. Social distancing sendiri merupakan suatu tindakan dimana setiap orang diharuskan agar tidak berdekatan antara satu dengan yang lainnya. Dengan menghindari segala macam perkumpulan atau pertemuan untuk mencegah penularan COVID-19. Oleh karena itu, segala kegiatan seperti kegiatan belajar mengajar (KBM) di sekolah maupun Universitas harus dilakukan di rumah atau dilakukan secara online untuk mencegah menyebarnya COVID-19 ini.

Ketika kita melakukan pembelajaran secara online tentunya kita memerlukan media sebagai sarana untuk pembelajaran. Oleh sebab itu berbagai Platfrom digunakan sebagai media pembelajaran oleh sekolah dan juga Universitas. Di Universitas sendiri terdapat berbagai platfrom yang digunakan di antaranya Google Classroom, Zoom Meeting, Whatsapp, Google Meet, dan sebagainya. Menurut penelitian yang kami lakukan 
platfrom yang paling banyak dimanfaatkan Universitas di wilayah DKI Jakarta dan Depok ialah Zoom Meeting.

Zoom Meeting sendiri merupakan sebuah media pembelajaran menggunakan video. Pendiri aplikasi Zoom Meeting yaitu Eric Yuan yang diresmikan tahun 2011 yang kantor pusatnya berada di San Jose, California. Aplikasi ini tidak hanya digunakan untuk pembelajaran saja tetapi bisa digunakan untuk urusan perkantoran maupun urusan lainnya. Platfrom ini gratis jadi dapat digunakan oleh siapapun dengan batas waktu empat puluh menit dan tidak ada batasan waktu jika akun kita berbayar. Dalam aplikasi Zoom Meeting ini kita bisa berkomunikasi langsung dengan siapapun lewat video. Oleh karena itu, memang cocok digunakan sebagai media pembelajaran.

Penelitian ini bertujuan untuk mengetahui seberapa besar pemanfaatan Zoom Meeting sebagai media pembelajaran di masa social distancing terhadap mahasiswa yang sedang menjalani pendidikan di Universitas willayah Jakarta dan Depok. Dalam kegiatan pembelajaran online dengan memanfaatkan penggunaan aplikasi Zoom Meeting, terdapat dua buah teori yang dapat meninjau kegiatan pembelajaran tersebut. Teori behavioristik merupakan salah satu teori yang membahas tentang berubahnya perilaku seseorang yang didasari dari sebuah pengalaman. Teori behavioristik menekankan terbentuknya perilaku yang terlihat dari hasil proses belajar [1]. Lalu, terdapat juga teori kognitif. Di dalam sebuah teori kognitif, tingkah laku individu dapat diarahkan melalui sudut pandang individu tersebut dan juga pengalamannya dalam situasi yang memiliki relasi dengan sebuah tujuan. Karena, dalam tingkah laku individu sifatnya dinamis. Sifat dinamis tersebutlah yang dipengaruhi oleh proses belajar [2].
Teori komunikasi pendidikan juga menjadi sebuah landasan dalam penelitian ini. Karena dalam proses pembelajaran tentunya melakukan proses komunikasi. Komunikasi yang dilakukan mahasiswa dengan dosen atau mahasiswa dengan mahasiswa lainnya. Dalam penelitian ini, apakah pemanfaatan aplikasi Zoom Meeting oleh Universitas di Jakarta dan Depok dinilai cukup baik dalam proses komunikasi atau tidak.

Manfaat dilakukan penelitian ini ialah untuk mengetahui dampak dan tanggapan setiap mahasiswa yang sedang menjalani pendidikan di Universitas wilayah DKI Jakarta dan Depok terhadap pembelajaran jarak jauh menggunakan aplikasi Zoom Meeting. Lalu, penelitian ini bermanfaat juga untuk menemukan sebuah solusi terhadap pemanfaatan aplikasi TIK yang diterapkan oleh pihak Universitas terhadap para mahasiswanya supaya pembelajaran jarak jauh menggunakan aplikasi yang berbasis TIK, dapat optimal sehingga para mahasiswa setiap Universitas tersebut tetap mendapatkan keuntungan dalam proses pembelajaran jarak jauh di tengah masa pandemi COVID-19

\section{METODE}

Penelitian ini dilaksanakan pada tahun 2020. Metode penelitian yang kami lakukan merupakan metode penelitian kualitatif. Creswell menjelaskan penelitian kualitatif didefinisikan sebagai suatu pendekatan atau penelusuran untuk mengeksplorasi dan memahami suatu gejala sentral [3]. Teknik pengambilan data yang kami lakukan ialah menggunakan google form. Kami menggunakan google form ini dikarenakan google form lebih cepat dan luas untuk menyebarkan kuesioner kepada subjek, di sisi lain karena adanya kebijakan social distancing ini maka tidak memungkinkan jika kami menggunakan metode wawancara secara langsung. Subjek penelitian ialah mahasiswa 
Universitas dengan domisili wilayah Jakarta dan Depok. Penelitian ini dilaksanakan untuk mengetahui seberapa besar pemanfaatan platform Zoom Meeting oleh Universitas di Jakarta dan Depok saat masa pandemi COVID-19. Rancangan penelitian dilakukan melalui beberpa tahap yaitu: (1) membuat beberapa pertanyaan yang akan diajukan kepada mahasiswa melalui google form, (2) menyebarkan pertanyaan secara online melalui sosial media berupa WhatsApp, (3) mengumpulkan dan menyaring data yang sudah diisi oleh mahasiswa untuk kemudian dianalisis.

Dalam teknik analisis data pada penelitian ini, menggunakan teknik analisis kualitatif dengan melakukan metode grounded theory [4]. Proses dengan menggunakan grounded theory ini dilakukan dengan pengkodean dan pengkategorian data terhadap fenomena penggunaan aplikasi Zoom Meeting oleh para mahasiswa di Universitas wilayah Jakarta dan Depok di saat pembelajaran jarak jauh selama masa pandemi COVID-19. Dalam analisis data menggunakan grounded theory, diawali dengan proses open coding yang dimana, (1) melakukan identifikasi terhadap fenomena penggunaan aplikasi Zoom Meeting oleh para mahasiswa di Universitas wilayah DKI Jakarta dan Depok di saat pembelajaran jarak jauh selama masa pandemi COVID-19, (2) melaukan kategorisasi dan penguraian gejala yang terdapat dalam hasil wawancara melalui google form dan WhatsApp.

Lalu setelah tahap open coding, dilanjutan dengan tahap axial coding yang dimana pada tahap axial coding menyatukan berbagai kategori penelitian dalam bentuk susunan dan hal ini merupakan gabungan cara bepikir induktif dan deduktif untuk merespon fenomena penggunaan aplikasi Zoom Meeting oleh para mahasiswa di
Universitas wilayah Jakarta dan Depok disaat pembelajaran jarak jauh selama masa pandemi COVID-19. Dan yang terakhir dilakukannya selective coding. Selective coding bertujuan untuk menyeleksi kategorisasi inti dan menyambungkan kategori lain pada penggunaan aplikasi Zoom Meeting oleh para mahasiswa di universitas wilayah DKI Jakarta dan Depok disaat pembelajaran jarak jauh selama masa pandemi COVID19.

\section{HASIL DAN PEMBAHASAN}

Penelitian ini dilakukan terhadap tiga puluh dua mahasiswa yang sedang menjalani pendidikan di Universitas wilayah Jakarta dan Depok. Tiga puluh dua mahasiswa yang sedang menjalani pendidikan di Universitas wilayah Jakarta dan Depok antara lain ialah berasal dari Universitas yang terdapat pada tabel berikut.

\section{Tabel 1. Nama Universitas dan Jumlah} Responden

\begin{tabular}{clc}
\hline No & \multicolumn{1}{c}{ Nama Universitas } & $\begin{array}{c}\text { Jumlah } \\
\text { Responden }\end{array}$ \\
\hline 1. & Universitas Indonesia (UI) & 4 \\
2. & $\begin{array}{l}\text { Universitas Muhammadiyah } \\
\text { Prof. Dr. Hamka (UHAMKA) }\end{array}$ & 20 \\
3. & $\begin{array}{l}\text { Universitas Negeri Jakarta } \\
\text { (UNJ) }\end{array}$ & 2 \\
4. & $\begin{array}{l}\text { Politeknik Negeri Jakarta } \\
\text { (PNJ) }\end{array}$ & 2 \\
5. & Universitas Gunadarma \\
6. & Universitas MH. Thamrin & 2 \\
& $\quad$ JUMLAH & 2 \\
\hline
\end{tabular}

Tabel 2. Jumlah Mahasiswa dan Semester yang Dijalani

\begin{tabular}{cc}
\hline Semester & Jumlah Mahsiswa \\
\hline 2 & 16 \\
4 & 9 \\
6 & 7 \\
JUMLAH & 32 \\
\hline
\end{tabular}

Sebelum adanya COVID-19 kegitan pembelajaran berjalan secara konvensional. Di setiap Universitas memiliki kegiatan 
pembelajaran yang berbeda-beda. Seperti PNJ (Politeknik Negeri Jakarta), mahasiswa di sana kegiatan belajarnya lebih kepada praktik, baik praktik di Universitas maupun di lapangan. Namun semenjak diberlakukannya social distancing mereka tidak lagi bisa melaksanakan praktik seperti biasanya. Begitupun mahasiswa yang ada di Universitas lainnya. Mereka sekarang beralih ke perkuliahan berbasis online atau e-learning dan kebanyakan dari mereka menggunakan aplikasi Zoom Meeting sebagai media untuk pembelajaran.

Dari ke tiga puluh dua mahasiswa yang sedang menjalani pendidikan di Universitas wilayah Jakarta dan Depok, semua mahasiswa tersebut baru pertama kali memakai Zoom Meeting untuk melakukan perkuliahan berbasis online. Para mahasiswa yang sedang menjalani pendidikan di Universitas wilayah Jakarta dan Depok sebelumnya menggunakan media pembelajaran berbasis online seperti Google Classroom, E-Learning universitas, dan Microsoft Teams. Fenomena penggunaan aplikasi Zoom Meeting di kalangan mahasiswa yang sedang menjalani pendidikan di Universitas wilayah Jakarta dan Depok, dimulai saat terjadinya wabah pandemi COVID-19 yang mengaharuskan para mahasiswanya melakukan pembelajaran jarak jauh. Tetapi, menurut hasil penelitian yang kami peroleh, penggunaan aplikasi Zoom Meeting dalam media pembelajaran jarak jauh dinilai tidak begitu efektif untuk para mahasiswa yang sedang menempuh studi di Universitas Jakarta dan Depok.

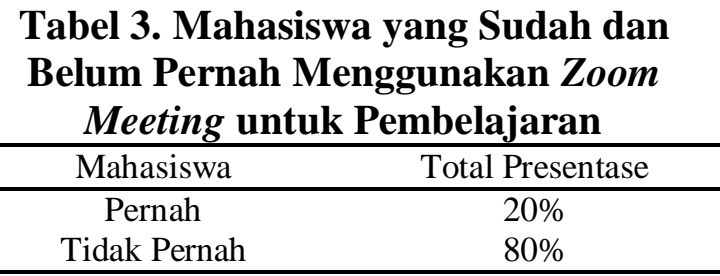

Tabel 3. Mahasiswa yang Sudah dan Meeting untuk Pembelajaran
Berdasarkan tabel memang banyak mahasiswa yang belum pernah menggunakan Zoom Meeting untuk pembelajaran sebelumnya, hal ini memang dikarenakan Universitas belum menggunakan metode e-learning sebagai media pembelajaran. Pihak universitas masih mengutamakan metode konvensional dibandingkan dengan $e$ learning. Alasan lain masih banyak dosen yang kurang paham akan teknologi sehingga pembelajaran dengan metode $e$ learning belum diterapkan. Namun ada juga mahasiswa yang sudah pernah menggunakan Zoom Meeting untuk pembelajaran sebelum adanya social distancing. Berdasarkan pendapat mahasiswa alasan mereka menggunakan Zoom Meeting sebelum adanya social distancing dikarenakan Zoom Meeting dinilai efisien, jadi ketika dosen tidak dapat hadir dikelas Zoom Meeting menjadi pilihan yang digunakan mahasiswa dan dosen untuk tetap bisa menjalankan pembelajaran apalagi aplikasi ini gratis dan sebelum adanya social distancing, Zoom Meeting memang sudah banyak digunakan di seluruh dunia sebagai media untuk pembelajaran. Jadi, ketika adanya COVID19 yang mengharuskan untuk melakukan kegiatan pembelajaran di rumah media Zoom Meeting yang banyak dipilih karena memang sudah banyak yang menggunakannya dan dinilai efisien.

Tabel 4. Pendapat Mahasiswa Tentang Efektivitas Penggunaan Zoom Meeting

\begin{tabular}{cc}
\hline Pendapat Mahasiswa & Total Presentase \\
\hline Efektif & $70 \%$ \\
Tidak Efektif & $30 \%$ \\
\hline
\end{tabular}

Hal-hal yang membuat tidak begitu efektif dalam pembelajaran jarak jauh menggunakan Zoom Meeting adalah (1) seringnya terjadi kendala seperti sinyal yang kurang bagus bagi mahasiswa yang tidak menggunakan wifi, (2) terdapat $30 \%$ mahasiswa yang terdapat mata kuliah 
praktikum merasa kesulitan karena, kualitas video di Zoom Meeting tidak begitu baik sehingga, 30\% mahasiswa tersebut merasa kesulitan dalam mengamati praktikumnya, (3) Sering terjadinya gangguan-gangguan suara aneh yang mengganggu aktivitas pembelajaran disaat sedang menyalakan voice.

Tetapi, penggunaan aplikasi Zoom Meeting dinilai sangat praktis bagi para mahasiswa. Hal tersebut dikarenakan dosen dan mahasiswa merasa lebih mudah melakukan komunikasi secara lisan dibandingkan secara tertulis. Proses komunikasi melalui lisan dapat menerima suatu hasil dan juga pengertian yang lebih jelas daripada melakukan komunikasi secara tertulis [5]. Lalu, selain itu penggunaan aplikasi Zoom Meeting yang termasuk salah satu dari media pembelajaran e-learning dapat memudahkan para mahasiswa dalam menghemat waktu dan biaya [6].

\section{SIMPULAN}

Bisa disimpulkan bahwa pemanfaatan aplikasi Zoom Meeting baru dilakukan ketika di masa Social Distancing ini yang mengharuskan mahasiswa untuk kuliah berbasis online. Kuliah yang dilakukan dengan Zoom Meeting ini dinilai kurang efektif sebab yang sering terjadi adalah kendala pada jaringan atau sinyal internet bagi mahasiswa yang tidak menggunakan wifi yang nantinya akan berdampak terhadap kualitas pembelajaran yang mereka terima. Namun kelebihan dari penggunaan Zoom Meeting ini dinilai praktis dan efisien bagi mahasiswa, karena dengan menggunakan Zoom Meeting ini komunikasi antara mahasiswa dan dosen lebih mudah dibandingkan berkomunikasi secara tertulis atau melalui chat.

Walaupun aplikasi Zoom Meeting dinilai kurang efektif namun disisi lain aplikasi ini dinilai lebih efisien dan praktis bagi mahasiswa. Untuk itu dengan adanya aplikasi Zoom Meeting ini diharapkan dapat membantu mahasiswa dalam hal pembelajaran berbasis online dan diharapkan mahasiswa dapat memanfaatkan aplikasi ini dengan seefektif mungkin.

Maka dari itu, mahasiswa dan dosen harus saling mengerti satu sama lain dalam pembelajaran jarak jauh ketika pandemi COVID-19 ini. Fenomena pandemi COVID-19 harus kita terima dengan baik. Karena, dengan adanya fenomena ini merupakan langkah dorongan terhadap setiap Universitas dalam memanfaatkan pembelajaran berbasis teknologi dan juga merupakan langkah untuk menuju revolusi industri 4.0 .

\section{UCAPAN TERIMA KASIH}

Dalam pembuatan artikel penelitian ini, kami mengucapkan terima kasih kepada dosen kami yaitu Bapak Andi Miskad M.Pd, yang telah membantu proses pembuatan artikel penelitian kami. Selanjutnya kami juga mengucapkan terima kasih terhadap para responden yang turut berpartispasi dalam pembuatan artikel penelitian kami. Tidak lupa juga kami ucapkan terima kasih terhadap Jurnal LPPM Unindra yang telah menyediakan wadah bagi kami untuk menulis dan membuat sebuah karya akademik. Apabila artikel penelitian kami dinilai tidak cukup baik, kami mengucapkan mohon maaf. Karena, kami sedang tahap belajar dalam pembuatan artikel penelitian. Karena hal ini sangat berguna sekali bagi kami untuk ke depannya. Memiliki sebuah pengalaman dalam penulisan artikel penelitian ini, merupakan sebuah pengalaman yang cukup berharga bagi kami. Sekali lagi kami ucapkan terima kasih.

\section{DAFTAR PUSTAKA}

[1] N. I. Nahar. "Penerapan Teori Belajar Behavioristik dalam Proses Pembelajaran". J. Nusant. (Ilmu 
Pengetah. Sos., vol. 1, no. 1, p. 3, 2016.

[2] S. Nurjati. "Bab II Pembelajaran Akidah Akhlak, Basis Humansitik, Pendekatan Active Learning". pp. 39-104, 2002.

[3] J. Raco. Metode Penelitian Kualitatif: Jenis, Karakteristik dan Keunggulannya. PT Grasindo, Jalan Palmerah Selatan 22 - 28, Jakarta 10270, 2010.

[4] I. G. Ayu dan N. Budiasih. "Metode Grounded Theory dalam Riset Kualitatif". J. Ilm. Akunt. dan Bisnis, pp. 19-27, 2013.

[5] Y. Wisman. "Komunikasi Efektif dalam Dunia Pendidikan". $J$. Nomosleca, vol. 3, no. 2, pp. 646654, 2017.

[6] P. Mahasiswa dan T. Media. "PERSEPSI MAHASISWA TENTANG MEDIA PEMBELAJARAN E-LEARNING STUDENTS PERCEPTION EELEARNING IN OBSTETRICS DEPARTEMENT", vol. II, pp. 107114, 2014. 